\title{
TRABALHANDO COM GÊNEROS E TIPOS TEXTUAIS NO ENSINO DE PORTUGUÊS COMO SEGUNDA LÍNGUA PARA SURDOS
}

Vanessa Gomes Teixeira é doutoranda em Ciências da Linguagem na Faculdade de Letras da Universidade do Porto (Portugal). Email: vanessa_gomesteixeira@ hotmail.com

\begin{abstract}
Resumo
Apesar de a proposta atual de inclusão enxergar a LIBRAS como língua materna dos surdos e prever o ensino de Português como segunda língua para essa comunidade, nota-se nos poucos materiais existentes que suas particularidades não são respeitadas, como a percepção visual, a LIBRAS, os aspectos culturais, entre outros. Levando em conta essa lacuna, o presente trabalho busca elaborar práticas pedagógicas voltadas para o ensino da modalidade escrita do Português como segunda língua para surdos.
\end{abstract}

Abstract
Despite current inclusion proposal seeing LIBRAS as
Deaf people`s mother language and envisioning that
Portuguese should be aimed at its written form and
taught as a second language for this community, we
notice, in little material developed, that several
particularities of these students are not respected, such
as visual perception, LIBRAS, the cultural aspects of
the deaf community, among others. With this field gap
in mind, present work seeks to elaborate best pedagogic
practices aimed to the written modality of Portuguese
as a second language for Deaf people.

\section{Abstract}

Deaf people`s mother language and envisioning that Portuguese should be aimed at its written form and taught as a second language for this community, we notice, in little material developed, that several particularities of these students are not respected, such as visual perception, LIBRAS, the cultural aspects of the deaf community, among others. With this field gap practices aimed to the written modality of Portuguese as a second language for Deaf people.

\section{1) Introdução}

No caso do ensino de Português como segunda língua para surdos, nota-se que, além da escassez de materiais pensados para esse público, os poucos existentes raramente abordam discussões sobre gêneros e tipologia textual ou propõem atividades que trabalhem com textos autênticos. Com isso, muitas vezes, a modalidade escrita da língua é ensinada apenas como um sistema de regras e não por meio das práticas sociais nas quais ela circula. Levando em conta essa lacuna na área, o presente trabalho busca elaborar atividades que trabalhem com gêneros e tipos textuais para o ensino da modalidade escrita do Português como segunda língua para surdos. Para alcançar meu objetivo, inicialmente faço uma breve revisão sobre os tópicos em questão. Depois, comento a importância desses dois conceitos no ensino de Português para surdos. Por fim, elaboro práticas pedagógicas iluminadas pelas etapas anteriores.

\section{2) Gêneros textuais e tipos textuais}

Segundo Bakthin (2000), a utilização da língua efetua-se em formas de enunciados orais e escritos relativamente estáveis, concretos e únicos, cujos elementos - como conteúdo temático, estilo e construção composicional - refletem as condições específicas e as finalidades das esferas da atividade humana das quais emergem. Esses enunciados são denominados de gêneros do discurso.

Bakthin (2000) defende a ideia de que, ao ouvir a fala do outro, sabemos de imediato prever qual é o gênero, sua extensão e sua estrutura composicional. Isso ocorre porque os gêneros do discurso organizam nossa fala, as formas gramaticais e sintáticas do texto. Logo, levando em 
conta seu intuito discursivo e seu destinatário, o locutor seleciona o gênero, os procedimentos composicionais e os recursos linguísticos do seu discurso.

Dialogando com as ideias acima, Marcuschi (2002) também defende que a língua é uma atividade social e, por isso, comunicação verbal só é possível por meio de um gênero textual. Segundo o autor, os gêneros textuais são fenômenos históricos vinculados à vida cultural e social, que contribuem para ordenar e estabilizar as atividades comunicativas cotidianas. São caracterizados a partir de suas funções comunicativas, cognitivas e institucionais e do domínio discursivo no qual são produzidos.

Como explica Marcuschi (2002), os tipos textuais se realizam nos gêneros textuais, podendo haver mais de um tipo de sequência tipológica em um mesmo gênero. As tipologias textuais designam sequências teoricamente definidas por traços linguísticos predominantes - como: aspectos lexicais e sintáticos, relações lógicas e tempos verbais - e podem ser categorizadas, segundo o autor, em cinco tipos: narração, argumentação, exposição, descrição e injunção.

Levando em conta que os textos se manifestam em gêneros textuais e nesses gêneros realizamse os tipos textuais, Marcuschi (2002) comenta que o conhecimento sobre o funcionamento dessa dinâmica mostra-se um conteúdo importante a ser trabalhando no processo de ensinoaprendizagem de uma língua. Nesse contexto, Köche, Boff \& Marinello (2013) explicam que as tipologias textuais são ferramentas essenciais a serviço dos gêneros e que precisam ser estudadas no interior de cada gênero.

Dessa forma, levando em conta a importância da relação entre gêneros e tipos textuais, as práticas pedagógicas do presente trabalho buscam propiciar a exposição do aluno à estrutura de alguns tipos textuais e promover reflexões acerca da estrutura dos gêneros trabalhados e suas principais características. Como as atividades elaboradas pretendem trabalhar com histórias infantis, são utilizados os seguintes gêneros: conto de fadas, história em quadrinhos, propaganda e notícia.

Em relação aos tipos textuais, busco trabalhar com a narração, presente nos gêneros selecionados para as atividades. Segundo Bronckart (1999), a narração é constituída por um processo de intriga que seleciona e organiza acontecimentos de modo a formar um todo com início, meio e fim. Com isso, como explicam Köche, Boff \& Marinello (2013), a sequência narrativa caracteriza-se por relatar situações ou fatos, reais ou imaginários, nos quais há personagens situados em um determinado tempo e lugar. Nesse sentido, o esquema narrativo pode ser dividido em: situação inicial ou apresentação, complicação, clímax e desfecho ${ }^{1}$.

Por fim, levando em conta o público alvo do material, as práticas pedagógicas em questão também levam em conta as especificidades da comunidade surda, que serão abordadas no tópico a seguir.

\section{3) Português para surdos}

\section{1) Ensino e trabalho com textos}


Ao aprender a Língua Portuguesa na modalidade escrita, os surdos lidam com aspectos específicos dessa língua. No entanto, levando em conta a importância da L1 na aprendizagem do Português como L2 na modalidade escrita por surdos, Fernandes (2006) comenta que, se houver uma base linguística assegurada pelo acesso à Língua Brasileira de Sinais (LIBRAS) como L1, substituindo a oralidade em conteúdo e função simbólica, o surdo conseguirá aprender a escrita do Português. Isso porque, como aponta Fernandes (2006), as palavras são processadas como um todo quando são percebidas pelo surdo, sendo reconhecidas em sua forma ortográfica e ligadas a uma significação. A partir desse processo cognitivo, os surdos podem aprender estruturas linguísticas sem conhecer seus sons. No entanto, se não houver sentido, não haverá leitura por parte do aprendiz, pois ler não é apenas memorizar palavras isoladas, e sim compreender e negociar sentidos na interação com o texto. Segundo Fernandes (2006):

Ler envolve compreender, identificar o significado global do texto, situando-o em uma determinada realidade social, fazendo parte de determinado gênero discursivo e atribuindo relações e efeitos de sentido entre as unidades que o compõem. [...] Entendemos que dominar esse processo envolve elaborar hipóteses de leitura sobre o texto que nos oportunizam a reflexão, aguçam a curiosidade e nos desafiam à busca pelo acerto. Levantar hipóteses requer a associação com informações anteriores, a antecipação sobre o texto e a seleção de ideias principais que o texto veicula (Fernandes, p.14).

É importante considerar também que o ensino da modalidade escrita do Português deve contemplar o desenvolvimento do letramento dos alunos, que, segundo Fernandes (2006), é o processo resultante das práticas sociais de "uso da escrita como sistema simbólico e enquanto tecnologia, em contextos específicos, para objetivos específicos"

Köche, Boff \& Marinello (2013) explicam que na situação inicial ou apresentação há uma situação estável. Já a complicação é provocada por uma força perturbadora, que instaura um desequilíbrio. O clímax é o auge da narrativa, que vai determinar o final. Por fim, o desfecho é o momento da narrativa em que o equilibro é retomado e instaura-se uma nova situação diferente da situação inicial.

(SCRIBNER; COLE apud KLEIMAN, 1995). Como explica a autora, alguns princípios norteadores do letramento são as concepções de que: a leitura e a escrita são processos complementares e dependentes; a leitura e a escrita devem estar sempre inseridas em práticas sociais; e há diferentes tipos e níveis de letramento, dependendo das necessidades do aprendiz no seu meio social e cultural.

No caso do ensino para surdos, deve-se promover também o Letramento Visual. Segundo Lebedeff (2010), cultura surda, experiência visual e cultura visual remetem ao letramento visual, que é explicado por Oliveira (2006) como a área de estudo que lida com práticas sociais e culturais de leitura e compreensão de imagens. Logo, o letramento visual busca compreender como os surdos leem e interpretam o mundo a partir de suas singularidades linguísticas e culturais e como eles utilizam social e culturalmente a escrita. Lebedeff (2010) comenta que estudos, como os de Reily (2003), mostram a importância da imagem na produção de conhecimento pela criança surda e salientam a importância de se utilizar a imagem como 
recurso cultural e como forma de instrumentalizar o pensamento. Dessa forma, Fernandes (2006) comenta que "aprender o Português decorrerá do significado que essa língua assume nas práticas sociais (com destaque às escolares) para as crianças e jovens surdos” (p. 6). Dialogando com essas ideias, Tomlinson (1999) explica que as práticas pedagógicas para o ensino de uma língua devem ter como objetivos: permitir que o aprendiz foque em aspectos formais da língua; encorajar os aprendizes a desenvolverem habilidades cognitivas para a aprendizagem e as utilizarem durante o processo de aprendizagem da segunda língua.

Para que esses objetivos sejam alcançados, a primeira preocupação durante o processo de elaboração de práticas pedagógicas deve ser a escolha dos textos que irão compor as atividades. Os textos, além de terem grande abrangência social, precisam fazer parte do cotidiano do aluno, pois, assim, a leitura permitirá que o aprendiz faça associações com seu conhecimento prévio e infira significados. Ademais, os textos também devem incentivar o engajamento do aprendiz, ou seja, promover sua atenção e energia. Isso fará com que ele busque sentidos na escrita, perceba características da língua e se aproxime do contexto de aprendizagem. Segundo Tomlinson (2003), algumas perguntas que podem definir critérios na escolha de textos são: (1) o texto promove o engajamento cognitivo e afetivo do aprendiz?; (2) o texto se relaciona com os contextos de vida dos aprendizes?; (3) o texto permite que os aprendizes relacionem seu conhecimento de mundo com o conteúdo abordado?; (4) o texto estimula diversas respostas por parte dos aprendizes?; (5) o nível de linguagem do texto se adequa ao nível dos aprendizes?; (6) o texto se adequa à idade e maturidade do aprendiz?; (7) o texto contribui para o desenvolvimento pessoal do aprendiz?; (8) os textos trabalhados expõem o aprendiz a diversos gêneros?; (9) os textos trabalhados expõem o aprendiz a diversos tipos de textos?. A partir dessas perguntas, podemos selecionar textos que permitem que os alunos se engajem no processo de aquisição de segunda língua e não enxerguem o processo de leitura e escrita apenas como um trabalho com as estruturas linguísticas.

Fernandes (2006) destaca também a importância de materiais ricos em imagens e ilustrações, pois eles permitem a contextualização visual do texto, a elaboração de hipóteses sobre os sentidos da escrita e a leitura das imagens, de modo que o aluno, a partir de seu conhecimento de mundo, poderá inferir possíveis efeitos de sentidos produzidos pelo texto. Após a seleção dos textos, Tomlinson (2003) sugere que sejam pensadas atividades que levem o aprendiz a experienciar o texto de diversas maneiras. Para que haja o desenvolvimento de um leitor crítico que vê o texto como objeto cultural, inserido em uma rede de relações sócio-históricas (Fernandes, 2006, p. 12), é preciso que seja propiciada a reflexão sobre os aspectos lexicais, gramaticais e funcionais do texto, que podem estar explícitos ou implícitos na organização textual.

Os aspectos funcionais dizem respeito à função social do texto, à prática social que lhe deu origem, ao veículo no qual ele se apresenta - como jornais, revistas, televisão, rádio, etc. - e aos seus propósitos - como informar, questionar, vender algo, etc. Já os aspectos lexicais falam sobre as palavras e os sentidos que constituem o discurso e sobre o vocabulário utilizado no texto, os efeitos de sentido produzidos devido às escolhas lexicais e a intertextualidade presente, ou seja, a relação daquele texto com leituras anteriores. Por fim, os aspectos 
gramaticais são as regras de organização do texto, que permitem construir enunciados compreensíveis na língua (FERNANDES, 2006). Esses tipos de conhecimento são ilustrados por Fernandes (2006) com a seguinte imagem:

Eixos do trabalho com a linguagem escrita

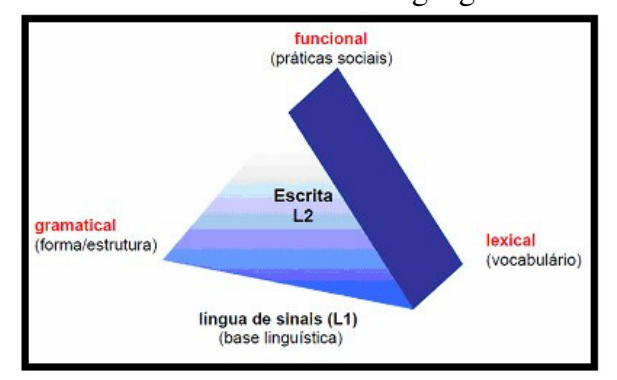

(FERNANDES, 2006)

Assim, podemos concluir que os pontos centrais na elaboração de práticas pedagógicas devem ser pautados na experiência visual, na LIBRAS e no trabalho com os mais variados gêneros textuais que circulam na sociedade, pois esses elementos possibilitarão que aluno surdo possa inferir sentidos do texto a partir do conhecimento visual do gênero trabalhado, ter contato com modelos de uso da língua e elaborar, testar e reelaborar suas hipóteses sobre a língua alvo. Como sugere Fernandes (2006):

A eliminação da apresentação de textos no quadro de giz. Todo texto proposto para leitura deve ser apresentado tal como ele é, ou como ele circula socialmente. Fim ao ritual de passar o texto no quadro com letra cursiva (que ninguém usa na sociedade, a não ser a escola), desprovido da riqueza de suas cores e imagens, da diversidade de tipos de letras em que é formatado (sempre de forma) e do veículo que lhe deu origem (publicação, embalagem folheto, etc.). Apenas utilizar textos em seu formato original (em transparência, multimídia, xerox ou originais) (FERNANDES, 2006, p. 12).

Por fim, como Tomlinson (2003) explica, antes de elaborarmos práticas pedagógicas, é fundamental que nos questionemos sobre a forma como as pessoas aprendem uma segunda língua. No caso da minha pesquisa, acredito que o Português deva ser ensinado como segunda língua para a comunidade surda, já que defendo que a LIBRAS é a língua materna do surdo e, por isso, deve ser ensinada como L1. Logo, as modalidades que trabalho com o meu aprendiz são a escrita e a leitura.

\section{2) A leitura}

Nos últimos anos, os materiais pedagógicos, que antes enxergavam o texto como um objeto, começam a trabalhar com as habilidades de leitura, as considerando um processo e encorajando a interação entre o leitor e o texto. Com isso, muda-se a visão do que seria um leitor "eficiente": se antes era a de um leitor passivo que lia a partir do vácuo, agora passa a ser a de um leitor 
que reage ao texto, criando, a partir de sua vivência e conhecimento de mundo, expectativas e ideias sobre o propósito daquilo que está lendo. Nesse contexto, Bartlett (1932) explica que o nosso conhecimento de mundo, baseado na experiência, nos permite prever o que pode acontecer e relacionar textos, o que influencia o processo de compreensão. Por exemplo, quando lemos um jornal, nós sabemos identificar, devido a nossa experiência, o layout, a ordem em que as informações aparecerão, o nível de formalidade esperado, entre outros.

McDough e Shaw (1993) também explicam que os leitores não buscam apenas decifrar o sentido de cada palavra isoladamente, e sim tentam buscar as informações gerais do texto e de sua organização para construir sentido. Em diversos casos, eles parecem usar as estratégias ascendentes e descendentes: enquanto o primeiro tipo diz respeito às estratégias que eles utilizam para identificar cada letra, juntando-as para formar unidades mínimas de sentido e depois chegar ao texto, o segundo tipo diz respeito ao fato de os leitores buscarem o sentido do texto a partir da interação entre suas experiências e seu conhecimento prévio de mundo.

Logo, as práticas pedagógicas elaboradas buscam desenvolver habilidades que façam com que o leitor interaja com diversos tipos e gêneros textuais, escolhendo suas estratégias de leitura de acordo com aquilo que irá ler. Isso porque, como apontam McDough e Shaw (1993), nós não lemos um poema do século XVII da mesma forma que lemos um jornal.

\section{3) A escrita}

McDonough e Shaw (1993) explicam que a escrita tem diversas funções - como narrar uma história, persuadir o leitor, argumentar sobre algum assunto, etc. — e demanda a habilidade de estruturar um texto cuidadosamente. Isso porque escrevemos diversos gêneros textuais e para diferentes interlocutores, como amigos, colegas de trabalho, alunos e até para nós mesmos. Esses fatores fazem com que a escrita apresente particularidades e, dependendo do contexto no qual está inserida, ela se diversifica em sua forma, estrutura, nível de formalidade e escolhas lexicais.

Em relação aos tipos de atividades, os autores comentam que há diversos tipos de tarefas voltadas para a escrita em sala de aula. Geralmente, as mais utilizadas são: o dever de casa, a construção de sentenças controladas e a redação livre. O dever de casa é o tipo de tarefa mais comum, pois geralmente os professores passam trabalhos para os alunos fazerem em casa, que serão corrigidos posteriormente. Já a construção de sentenças controladas promove um modelo de sentença e pede ao estudante para construir uma outra frase com a mesma estrutura, mas com o léxico diferente. Esse tipo de atividade pode também fornecer uma frase com determinadas palavras faltando e pedir para o aprendiz completá-la com a forma que falta. Por fim, a redação livre pretende fazer com que o aprendiz crie um texto a partir de um tópico: às vezes, ele deve escrever sobre algum assunto pessoal - como seus hobbies ou o que ele fez no fim de semana; em outros materiais, há textos sobre o tema que será trabalhado na redação e perguntas de compreensão como estímulos para o aluno.

Como aponta McDonough e Shaw (1993), esses procedimentos trabalham com a escrita focando apenas no produto final, que seria o texto, e o papel do professor nesse contexto seria 
julgar a produção textual elaborada pelo aprendiz. Logo, essas atividades não enxergam a escrita como um processo, nem pensam em discussões voltadas para a reflexão do seu papel em contextos reais de comunicação.

Dialogando com a visão que os autores apoiam, surgem materiais pedagógicos que começaram gradualmente a refletir sobre a diversidade e complexidade do processo da escrita. Raimes (1983), por exemplo, enxerga a escrita não apenas como sentenças isoladas, e sim a partir de textos que os autores escrevem com um propósito e para um leitor.

Levando em conta que o processo é uma importante ferramenta para o trabalho da escrita, Raimes (1983) lista nove momentos importantes desse processo: (1) reflexão sobre o processo; (2) sintaxe; (3) gramática; (4) aspectos mecânicos (caligrafia, ortografia, pontuação); (5) organização lógica de ideias; (6) escolhas lexicais; (7) propósito; (8) audiência; (9) conteúdo. Em relação a essas etapas do processo de escrita, vale destacar (7) o propósito e (8) a audiência. Nunan (1999) propõe atividades para desenvolver a conscientização do aprendiz sobre o propósito da escrita, e não apenas a questão gramatical das sentenças. Já em relação à audiência, diversos autores (Byrne, 1988; Hedge, 1988; Tribble, 1996) afirmam que escrever é organizar uma mensagem em palavras tendo um tipo de leitor em mente. A esse respeito, McDonough e Shaw (1993) propõem atividades que trabalham com diversos gêneros e também com diversos públicos. Dessa forma, o professor poderá promover conscientização sobre o que é escrever: pensar sobre o que queremos falar (conteúdo) e para quem queremos falar (o leitor).

\section{4) Propostas de práticas pedagógicas}

Dialogando com as ideias apresentadas nos tópicos anteriores, apresento sugestões de práticas pedagógicas para o ensino de Português como segunda língua para alunos surdos. As atividades têm como eixo temático o papel da mulher, e, para desenvolver minhas atividades, utilizo gêneros autênticos, materiais ricos em imagens e busco trabalhar com as especificidades do público em questão.

Seguindo as sugestões de Saliés (2011), organizei as práticas a partir de préatividades, atividades e pós-atividades. O objetivo geral do material é propiciar oportunidades de contação de histórias e os objetivos específicos são propiciar exposição à estrutura da narrativa. A seguir são apresentadas algumas propostas de práticas pedagógicas.

PRÉ-ATIVIDADES: têm como objetivo introduzir o tema que será trabalhado e construir o conhecimento prévio, inserindo o aprendiz em práticas sociais e fazendo com que ele vivencie situações de uso.

$1^{a}$ atividade - Iniciar um debate sobre o tema para que os alunos troquem ideias sobre o que já sabem. Espera-se que eles falem em LIBRAS para que se sintam confortáveis em expressar suas opiniões.

Revista Escrita

Rua Marquês de São Vicente, 225 Gávea/RJ CEP 22451-900 Brasil

Ano 2017. Número 22. ISSN 1679-6888. escrita@ puc-rio.br 


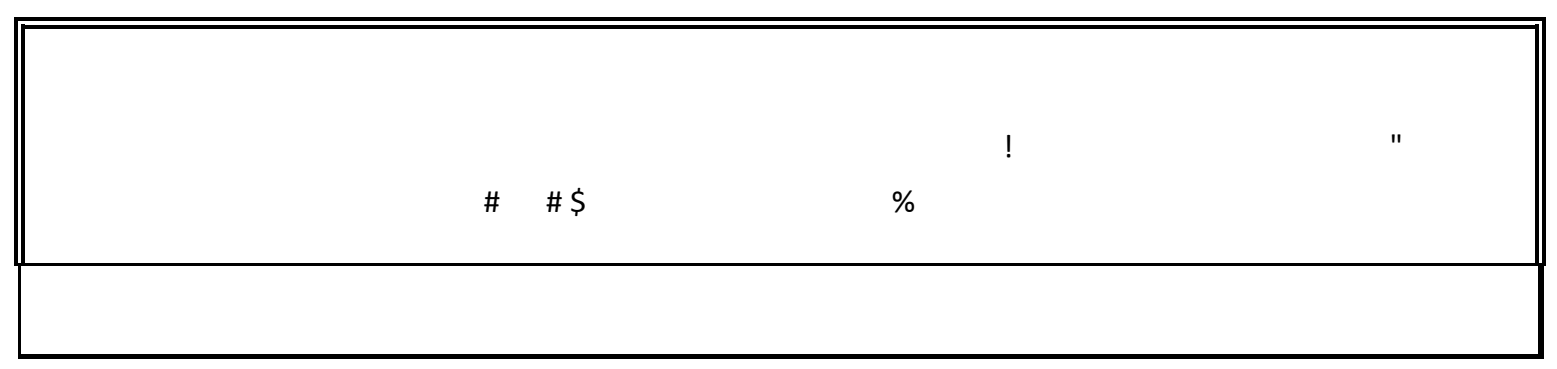

$2^{a}$ atividade - Apresentar para a turma diversas figuras dos contos infantis mais conhecidos e pedir que eles relacionem as imagens com seus respectivos títulos. Novamente, recomenda-se que os alunos façam essa atividade em LIBRAS.

Para a elaboração dessa atividade, sigo as sugestões de White (1981), que fala sobre alguns encaminhamentos de práticas voltadas para a leitura, como: incentivar o interesse e a motivação ao relacionar o tópico do texto com o conhecimento prévio.

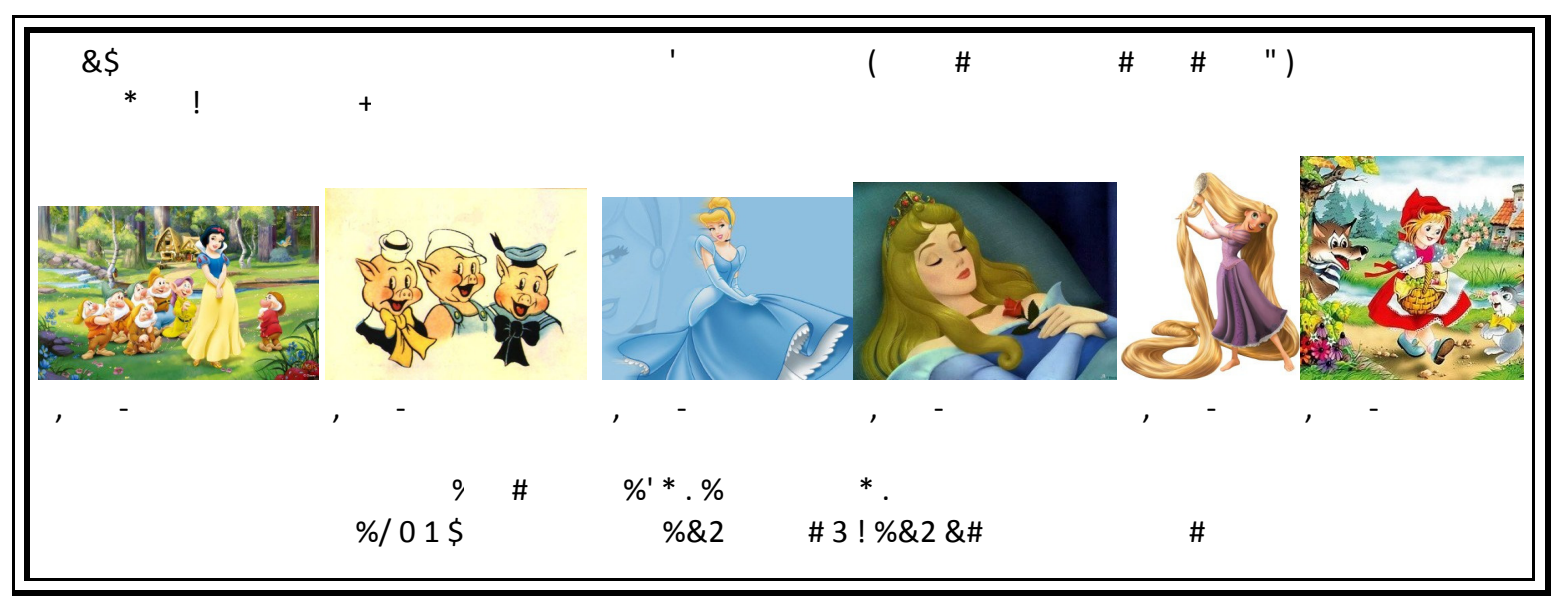

$3^{\text {a }}$ atividade - Pedir que os alunos contem uma das histórias da atividade 2 e façam um resumo da mesma em Português.

Busco, novamente, trabalhar com o conhecimento prévio e com atividades em grupos, nas quais os aprendizes têm a oportunidade de coconstruir conhecimento. O papel do professor nessa atividade é, junto com os alunos, propiciar reflexões acerca da diferença de estrutura entre a LIBRAS e a Língua Portuguesa.

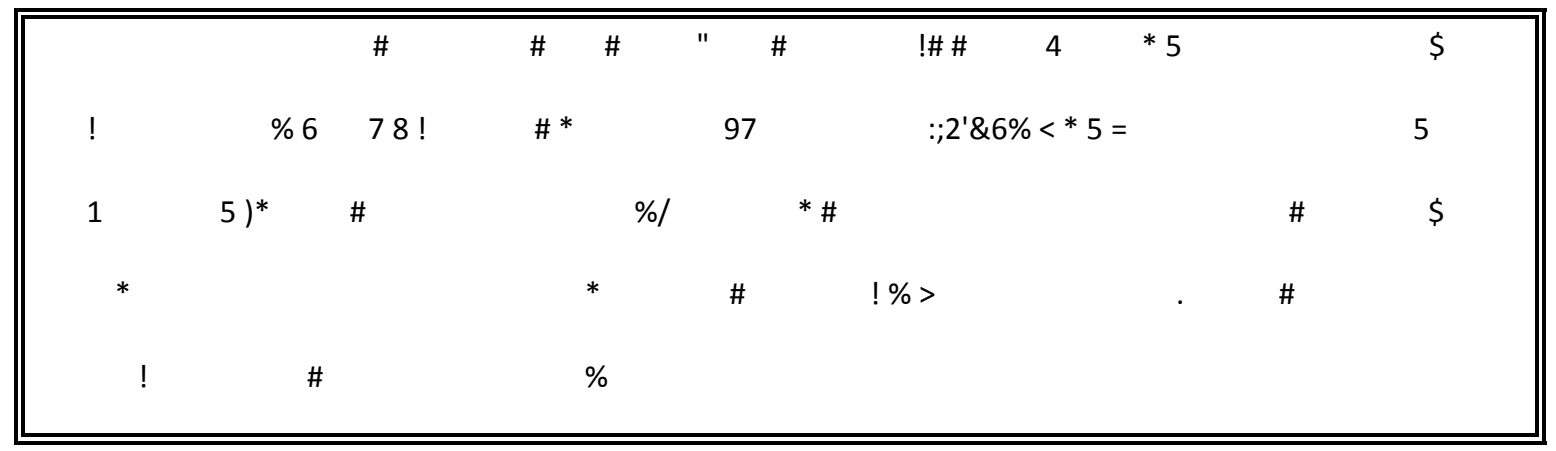

$4^{\text {a }}$ atividade - Apresentar dois vídeos sobre histórias infantis em LIBRAS. 


\section{Sugestões de vídeos...}

Há na Internet, no site do Youtube, muitos contos infantis traduzidos para LIBRAS. Vamos assistir a alguns?

Chapeuzinho Vermelho em Libras:

Disponível em: https://www.youtube.com/watch?v=JuCVU9rGUa8

Os três porquinhos em Libras:

Disponivel em: https://www.youtube.com/watch?v=JdpN-Es1p5Y
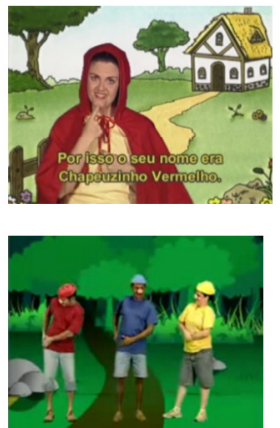

Nessa atividade, levo em conta a importância da

tecnologia como forma de incentivar o engajamento dos aprendizes no processo de ensino-aprendizagem de PL2. Além disso, com os vídeos, busco trabalhar o conhecimento prévio dos alunos surdos, que, muitas vezes, não têm acesso às histórias infantis, já que a maioria dos pais não sabe LIBRAS.

$5^{\text {a }}$ atividade - Iniciar um debate, em LIBRAS, sobre quais são as ideias principais de ambos os vídeos e quais as características semelhantes entre as histórias. Por fim, perguntar o que seria, na opinião deles, uma história infantil e suas principais características.

O objetivo dessa atividade é fazer com que os alunos elaborem hipóteses sobre a estrutura da história, trabalhando com o tipo textual narrativo, suas principais características e o gênero história infantil.

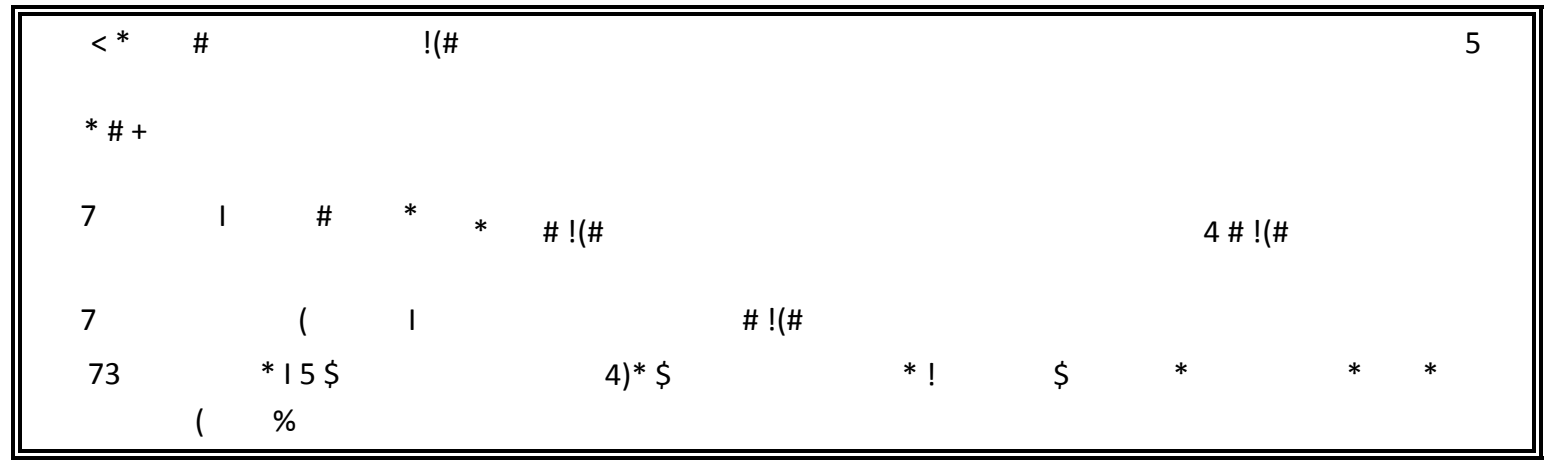

ATIVIDADES - busco com as atividades trabalhar a combinação entre o input compreensível e o foco na forma por meio da reflexão sobre o tema que está sendo trabalhado, no caso, elementos da narrativa.

$1^{\mathrm{a}}$ atividade - Ler com a turma o texto A Branca de Neve e os sete anões e responder as perguntas a partir de debates em LIBRAS.

Escolhi o texto para essa atividade devido a sua relação com o cotidiano do aluno. Busquei também materiais ricos em ilustrações, de forma que as imagens pudessem ajudá-lo a coconstruir o sentido. Após o texto, há perguntas de interpretação, cujos objetivos são fazer com que o aprendiz reflita sobre a história e sua estrutura e elabore hipóteses sobre os elementos da narrativa. 


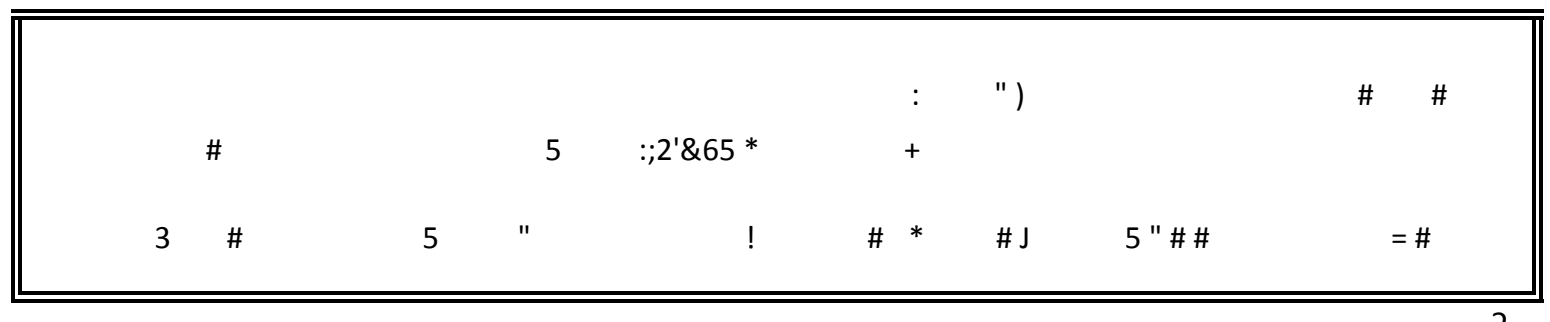




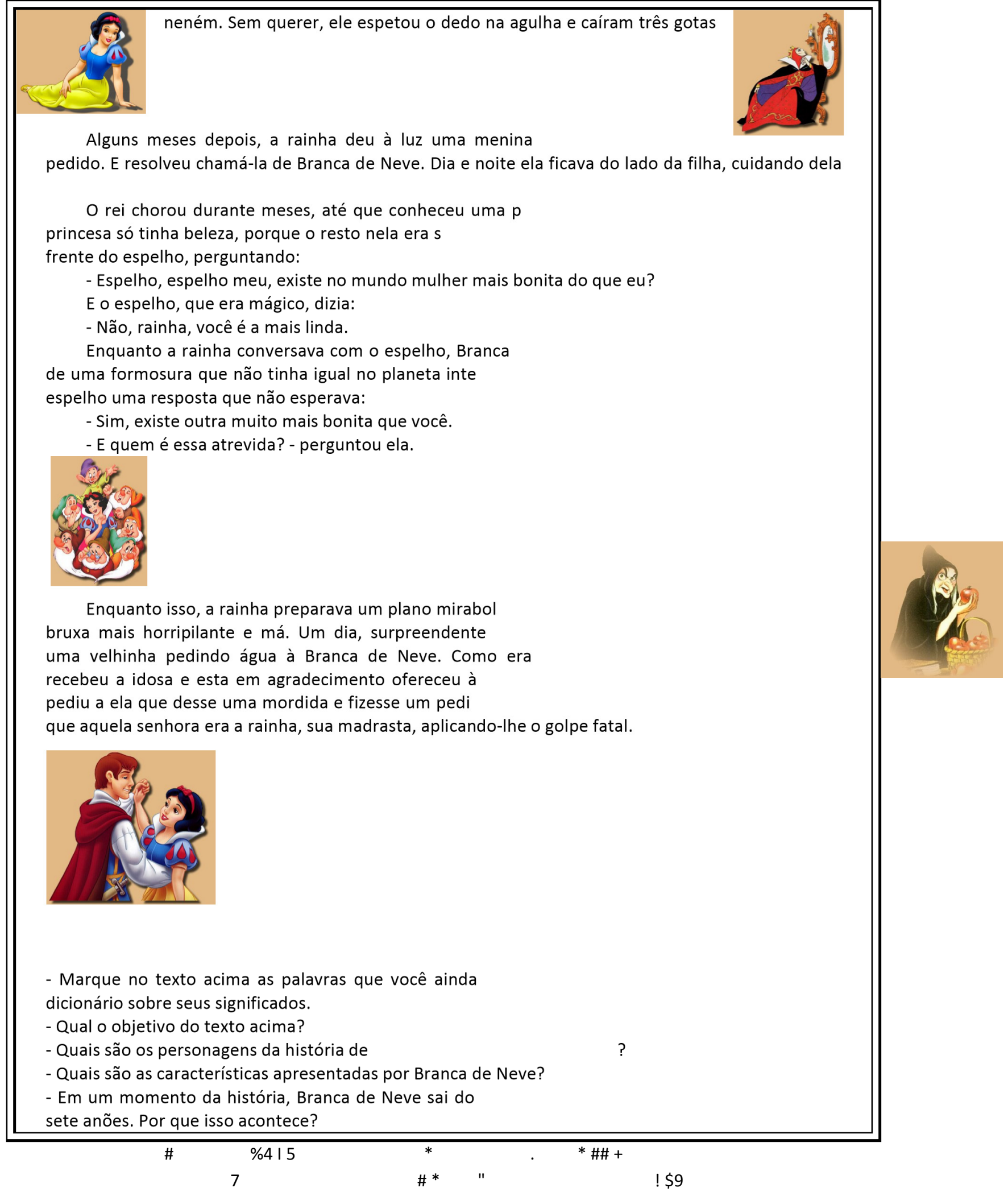

Revista Escrita

Rua Marquês de São Vicente, 225 Gávea/RJ CEP 22451-900 Brasil Ano 2017. Número 22. ISSN 1679-6888. escrita@ puc-rio.br 


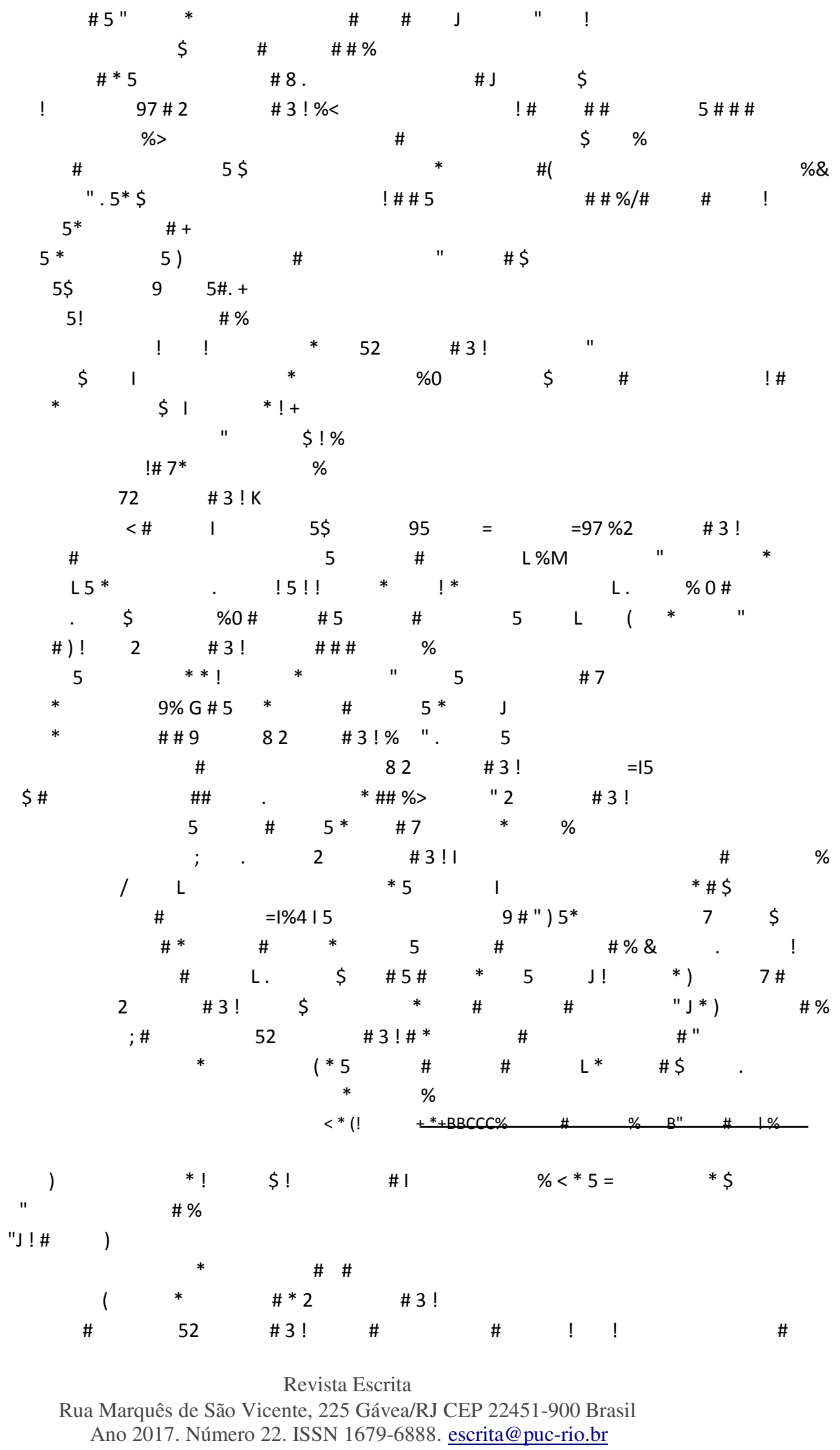




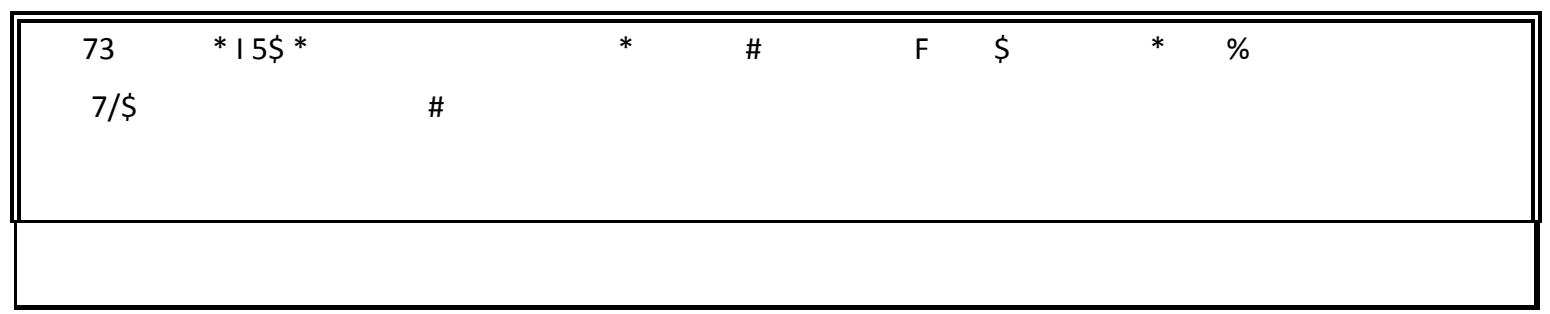

$2^{\mathrm{a}}$ atividade - Trabalhar elementos da narrativa.

É o momento do encontro em que conceitos são introduzidos a partir das respostas dadas na $1^{a}$ atividade e dos textos trabalhados nos encontros anteriores.

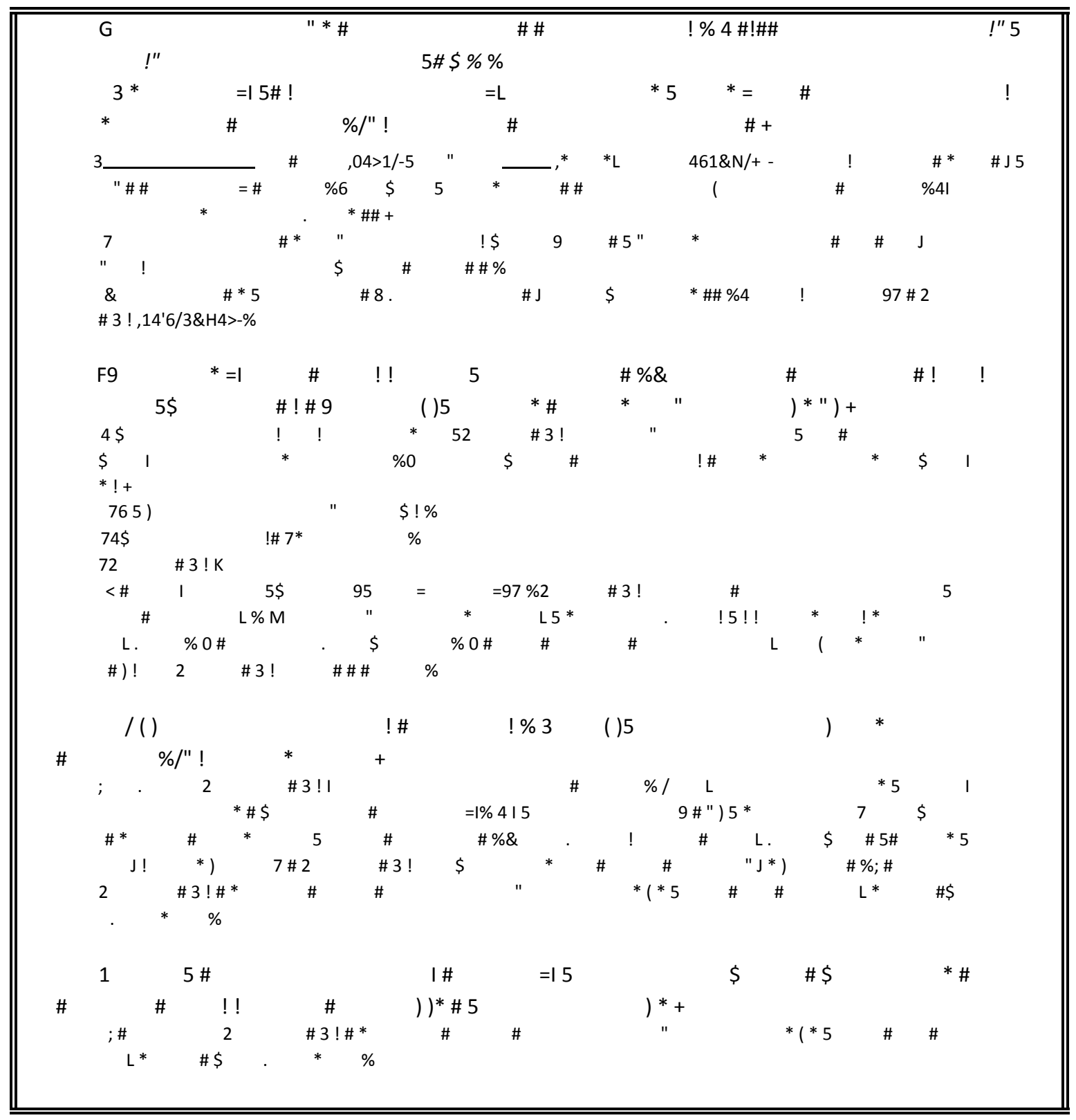

Revista Escrita

Rua Marquês de São Vicente, 225 Gávea/RJ CEP 22451-900 Brasil Ano 2017. Número 22. ISSN 1679-6888. escrita@ puc-rio.br 
$3^{\text {a }}$ atividade - Apresentar o vídeo Cinderela em LIBRAS e pedir que o aluno, em casa, faça um esquema organizando a história vista de acordo com os elementos da narrativa.

Para casa...

Veja agora o vídeo Cinderela em LIBRAS e faça um esquema, organizando a história vista de acordo com os elementos da narrativa aprendidos.

Cinderela em Libras: https://www.youtube.com/watch?v=aw2ts6GfuLI

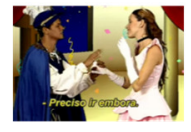

\begin{tabular}{|c|c|}
\hline ELEMENTOS DA NARRATIVA & TRECHO DO VÍDEO \\
\hline Apresentação & \\
\hline Complicação & \\
\hline Clímax & \\
\hline Desfecho & \\
\hline
\end{tabular}

$4^{\text {a }}$ atividade - Ler com a turma a propaganda da loja $\mathrm{O}$ Boticário e responder as questões por meio de debate em LIBRAS.

Esta atividade tem como objetivo propiciar a coconstrução de sentido pelo aluno ao fazer relações entre a publicidade e o conto A Branca de Neve. Escolhi trabalhar com uma propaganda, porque é um gênero rico em imagens, com grande abrangência social e que faz parte do cotidiano do aluno. 
Você conhece a loja O Boticário? Debata com seus amigos sobre os possíveis produtos que essa loja

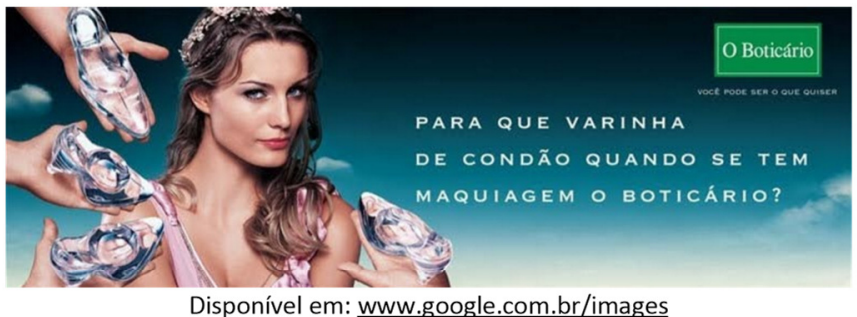

il Cinderela

Cinderela?

! \# $\%$ * $5 \quad$ \# $\quad * * \quad \# \quad$ " ) +

$7 \& * * \quad \mathrm{~J} ! \# \quad ）$

* $\quad$ \# $\quad+$

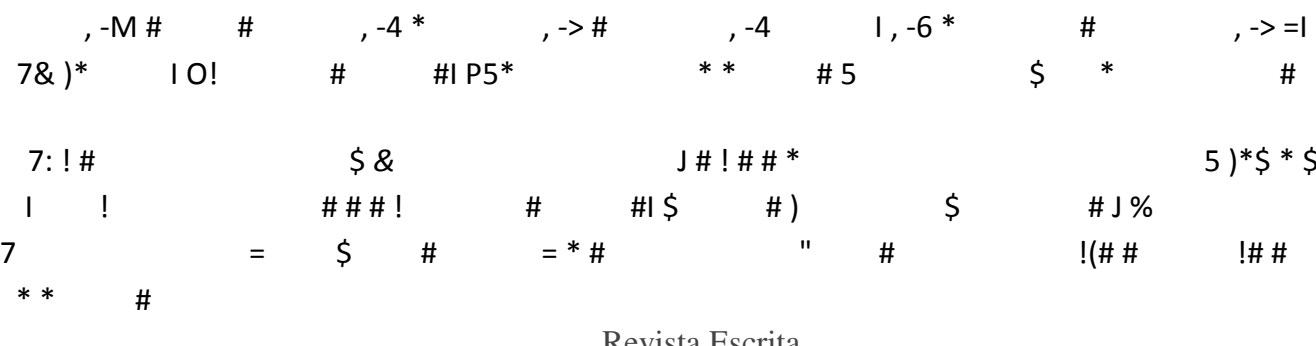

Rua Marquês de São Vicente, 225 Gávea/RJ CEP 22451-900 Brasil Ano 2017. Número 22. ISSN 1679-6888. escrita@ puc-rio.br 


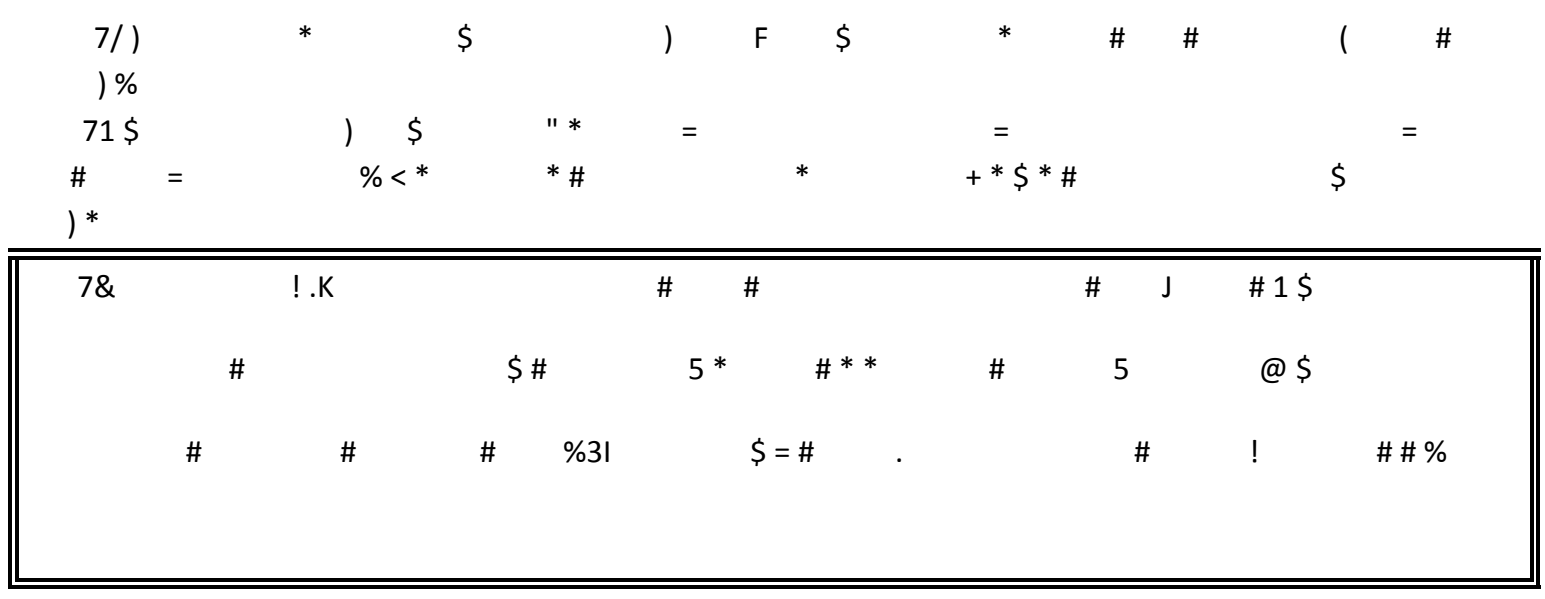

$5^{\mathrm{a}}$ atividade - Primeiramente, cada aluno deverá apresentar sua história em LIBRAS. Após essa primeira etapa, a turma deverá reconhecer os elementos da narrativa de cada história.

PÓS-ATIVIDADES - busco com as pós-atividades reforçar as associações construídas ao longo do processo pelo aprendiz e fazer com que o aluno reflita sobre o que ele aprendeu, descubra o que ele não aprendeu e avalie a importância (ou não) do tema para a sua vida. Aqui também busco propiciar oportunidades para comparações, síntese e elaborações que envolvam processos descendentes e habilidades cognitivas superiores.

$1^{\text {a }}$ atividade - Apresentar os seguintes materiais para os alunos: um exemplar da revista Isto é, um exemplar do jornal Folha Dirigida e vídeos legendados com trechos do Jornal Nacional e do Brasil Urgente. Depois, propor um debate perguntando aos alunos quais características dos materiais.

$2^{a}$ atividade - Antes de ser trabalhado o texto Como a imprensa brasileira noticiaria hoje a história de Chapeuzinho Vermelho? é apresentado para os alunos o texto abaixo, que também fala sobre essas mídias. 
Você conhece O Jornal Nacional ou o Brasil Urgente? E a revista Isto é e o jornal Folha Dirigida? Leia abaixo mais sobre essas mídias:

O Jornal Nacional é um telejornal brasileiro, produzido e exibido pela Rede Globo. É o telejornal mais assistido e reconhe ao longo de sua existência, acumulado diversos prêmios.
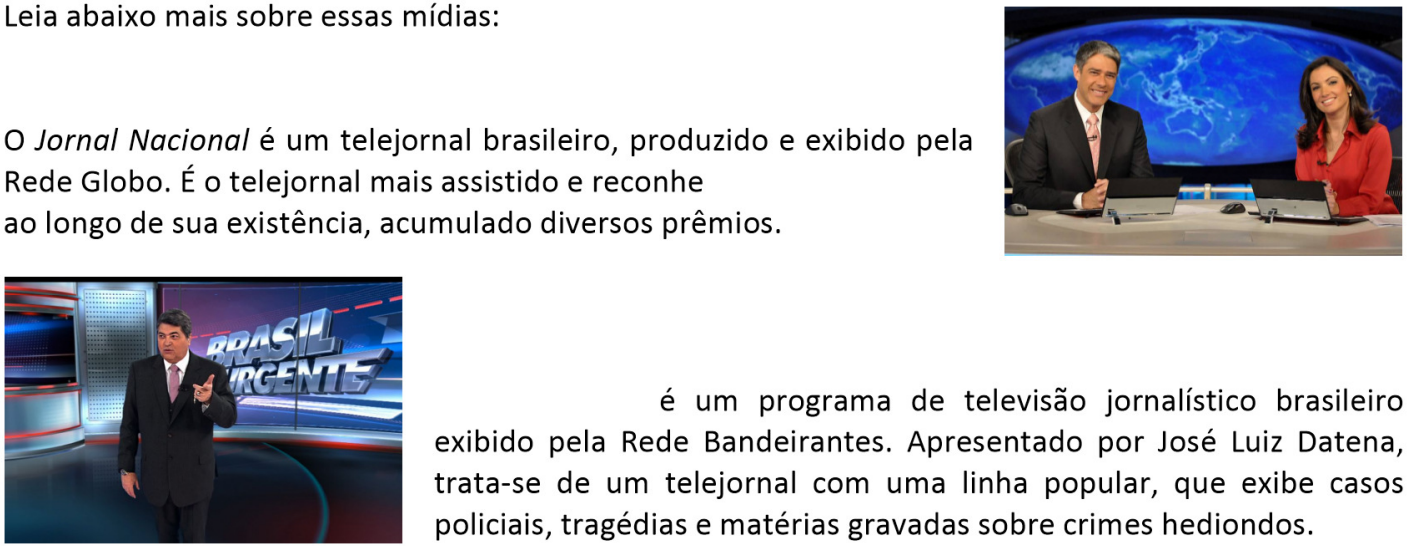

é um programa de televisão jornalístico brasileiro exibido pela Rede Bandeirantes. Apresentado por José Luiz Datena, trata-se de um telejornal com uma linha popular, que exibe casos policiais, tragédias e matérias gravadas sobre crimes hediondos.

A revista Isto É é uma revista semanal brasileira de informações gerais, publicada pela Editora Três.

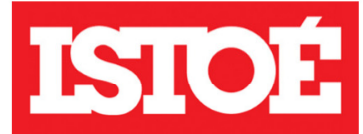

FOLHA O jornal A Folha Dirigida é tri-semanal e especializado em educação, concursos DIRIGIDA públicos e empregos. É um jornal segmentado, com noticiário focado na carreira pública.

\begin{tabular}{cccc} 
& $5 * \# . \#$ & \multicolumn{2}{c}{)$^{*}$} \\
$\#$ & & $\# \#{ }^{*}(5$ & $\# 5$ \\
$\# \# !$ & $*$ & $\%$
\end{tabular}

\begin{tabular}{|c|c|c|}
\hline () & & $\#$ \\
\hline )"\# * & ' \# 2 \# & $\%$ \&* \\
\hline 7\# & J & \\
\hline 5 & \# & ! \# \\
\hline
\end{tabular}




\begin{tabular}{|c|c|c|c|c|c|c|}
\hline $\begin{array}{l}7 \\
\text { ) }\end{array}$ & $=$ & \# & $=* \#$ & " & \# & $=1^{*}$ \\
\hline
\end{tabular}

$3^{\text {a }}$ atividade - Apresentar mais exemplares dos meios de comunicação citados no texto acima. Depois, dividir a turma em grupos e pedir para cada um desses pesquisar sobre um dos materiais. Na aula seguinte, cada grupo apresentará em LIBRAS a pesquisa realizada.

$4^{\text {a }}$ atividade - Fazer a leitura em grupo do texto Como a imprensa brasileira noticiaria hoje a história de Chapeuzinho Vermelho? e propor novos questionamentos sobre os sentidos possíveis do texto. A atividade em questão será realizada em LIBRAS.

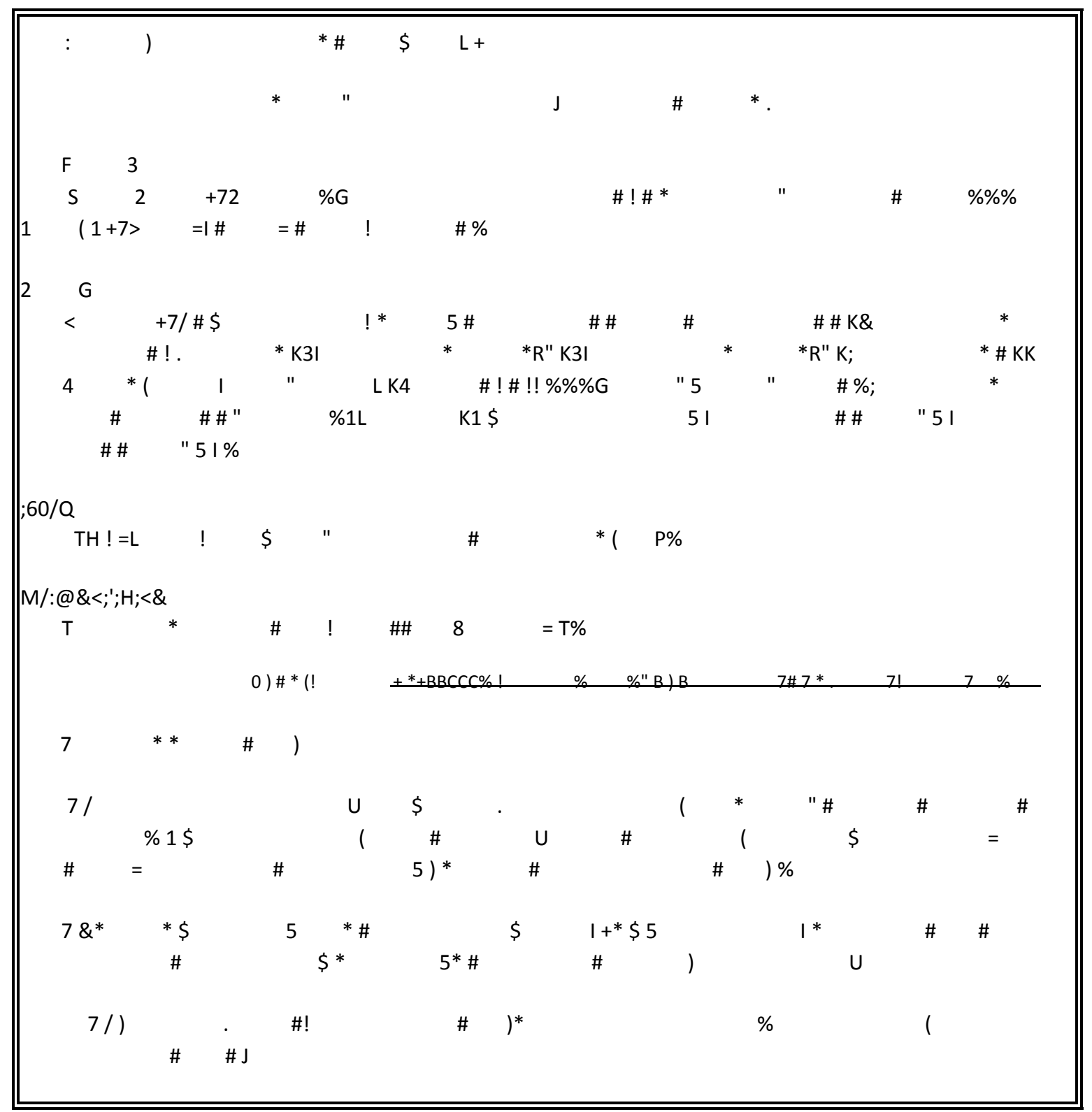




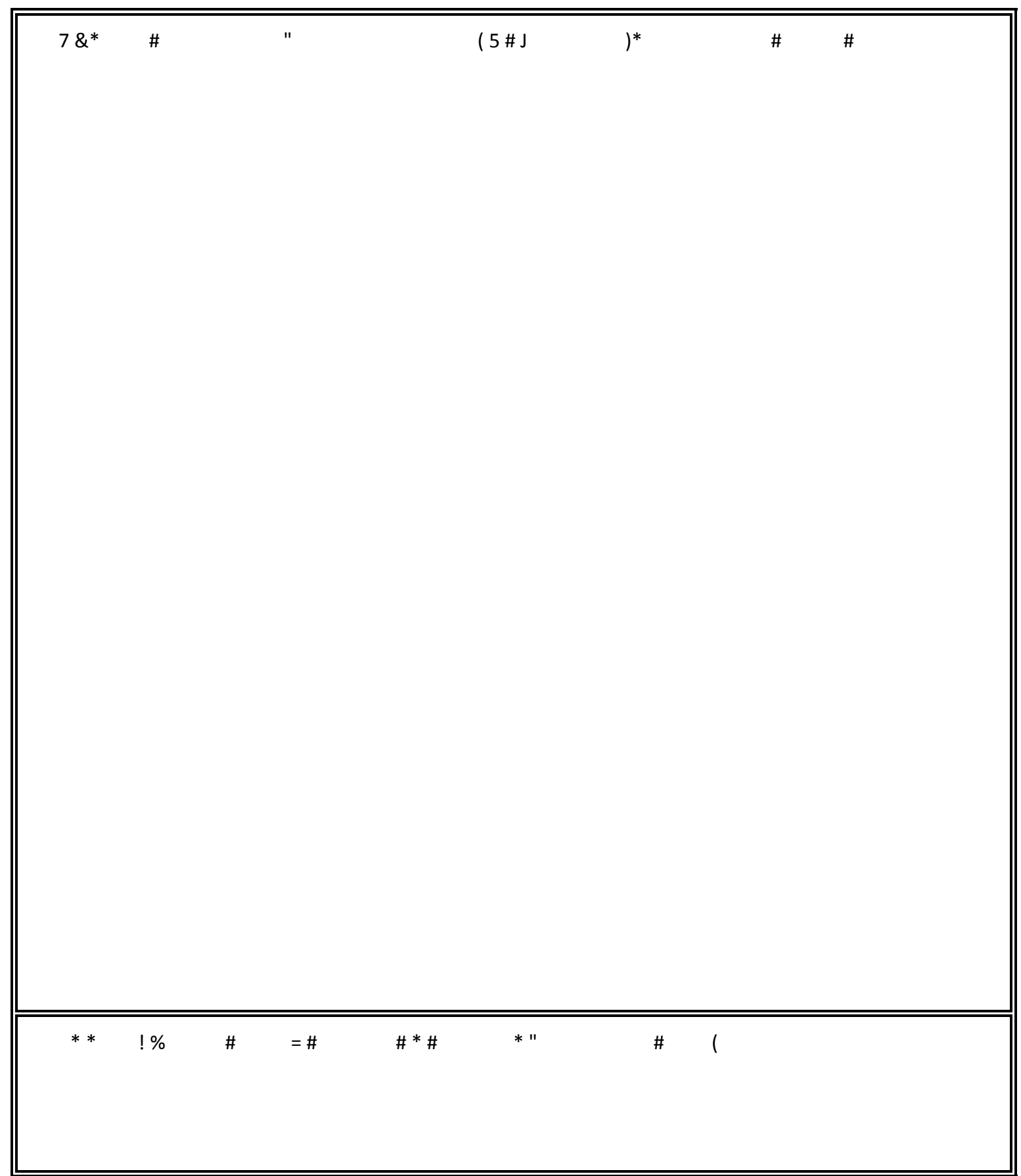

$5^{a}$ atividade - dialogando com a ideia do texto Como a imprensa brasileira noticiaria hoje a história de Chapeuzinho Vermelho?, o objetivo da 8 atividade é trabalhar com adaptações dos contos de fadas para a atualidade e propiciar reflexões sobre como essas histórias sinalizam a mudança de visão em relação ao papel da mulher na sociedade. 


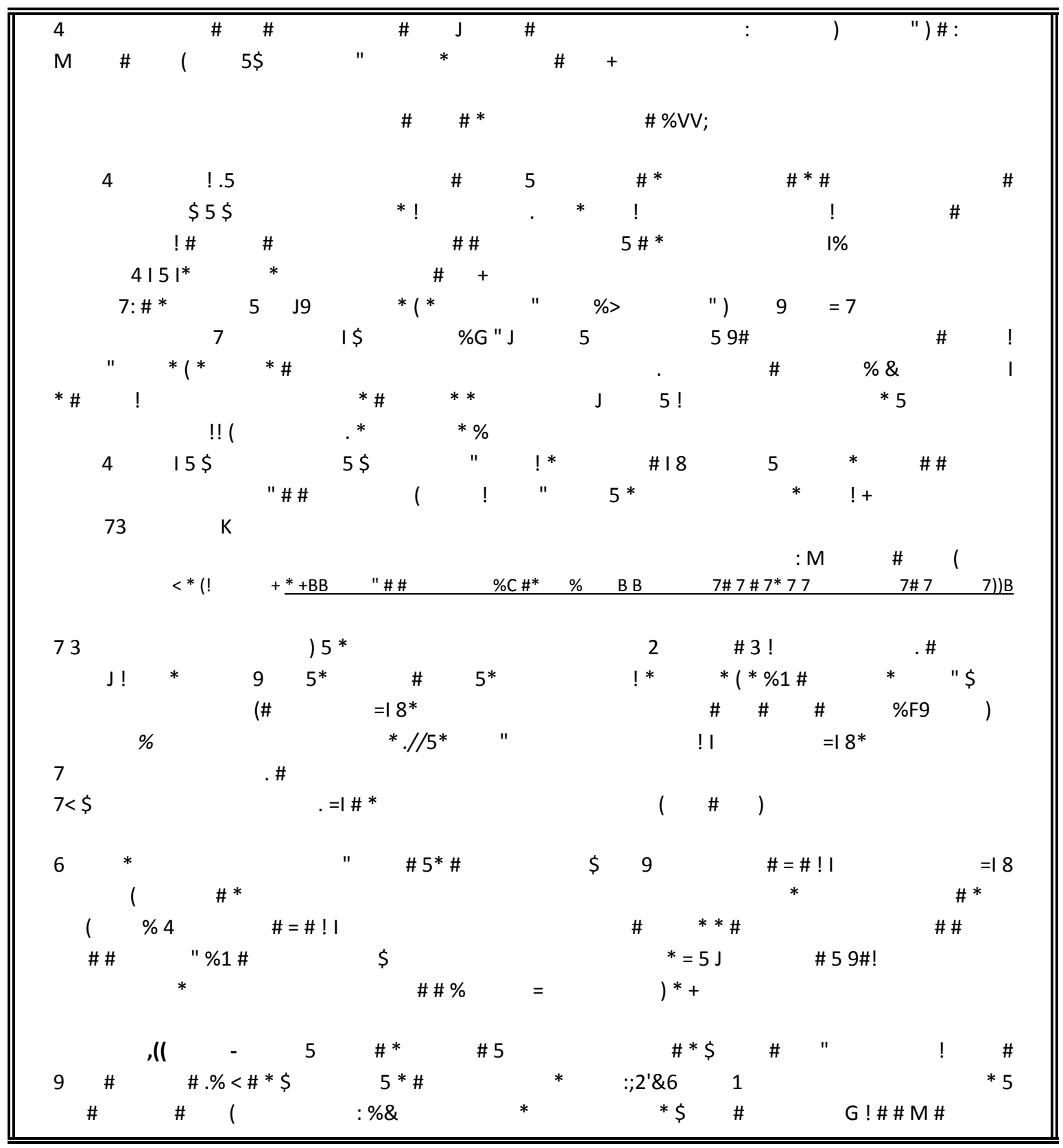


de Santa Catarina.

Heloise Gripp Diniz é uma pesquisadora surda e professora de LIBRAS no curso de especialização da faculdade UFRJ. Sua pesquisa é voltada para a área de línguas de sinais em níveis

linguísticos.
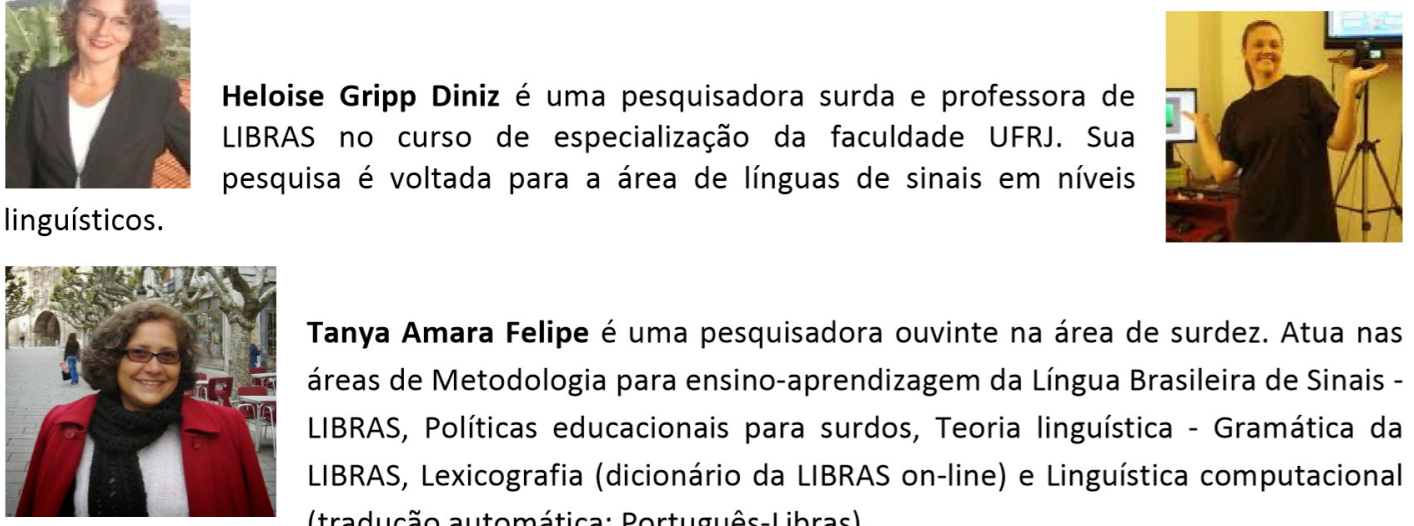

Tanya Amara Felipe é uma pesquisadora ouvinte na área de surdez. Atua nas áreas de Metodologia para ensino-aprendizagem da Língua Brasileira de Sinais LIBRAS, Políticas educacionais para surdos, Teoria linguística - Gramática da LIBRAS, Lexicografia (dicionário da LIBRAS on-line) e Linguística computacional (tradução automática: Português-Libras).

$6^{\text {a }}$ atividade - Propor uma pesquisa para o aluno fazer em casa.

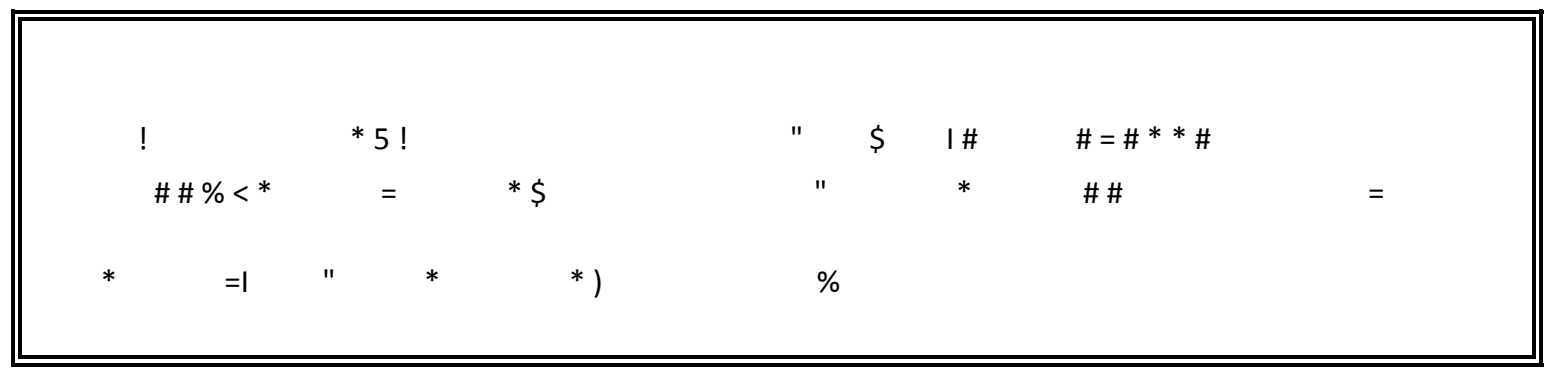

$7^{\text {a }}$ atividade - Corrigir o trabalho de casa e pedir que os alunos o apresentem em LIBRAS.

Nesse momento do encontro, é importante que o professor, a partir das pesquisas, destaque alguns pontos, como, por exemplo, a relação entre as personagens Branca de Neve e Cinderela e a visão que a sociedade tinha da mulher antigamente e a relação entre a princesa retratada por Veríssimo e o papel da mulher na sociedade de hoje em dia.

$8^{\text {a }}$ atividade - Propor um novo trabalho de casa com o objetivo de desafiar os alunos a relacionarem a temática sobre o papel da mulher moderna e estrutura da narrativa.

Nessa atividade, dialogo com os estágios apontados por White and Arndt (1991), que enxergam a escrita como um processo construído pelos seguintes momentos: (1) criação e organização das principais ideias, (2) foco e escolha das principais ideias, (3) estruturação do texto, (4) elaboração do rascunho, (5) avaliação do texto que foi elaborado e (6) revisão do que foi escrito para elaborar a versão final do texto.

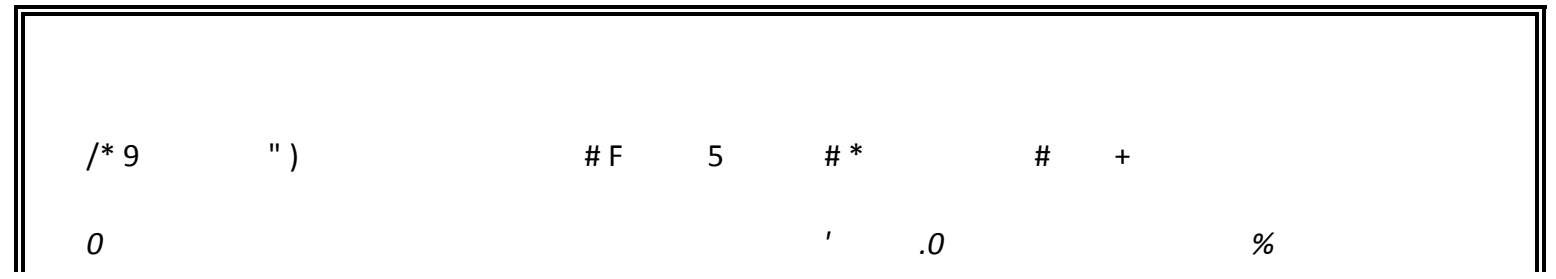




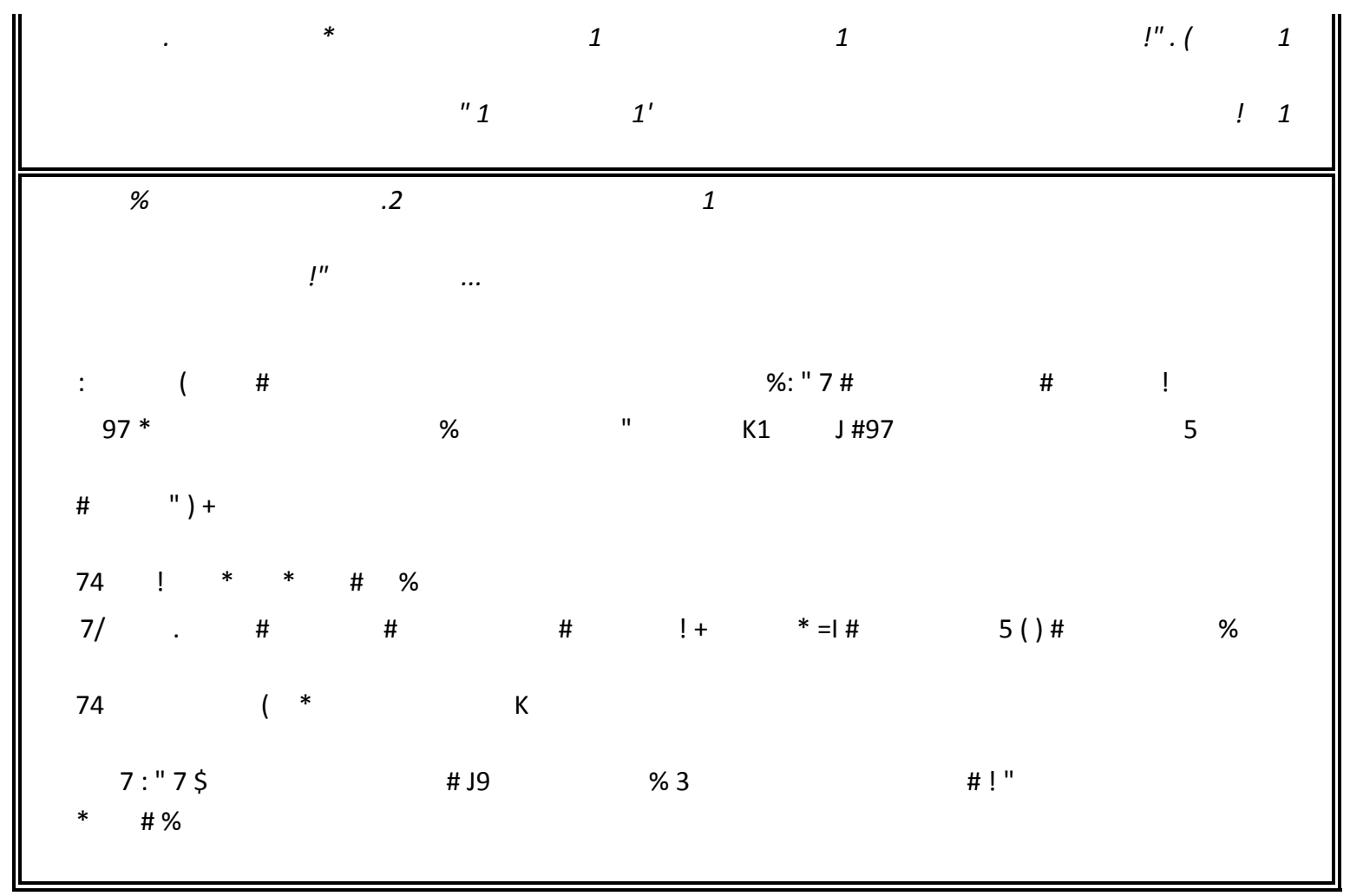

$9^{\text {a }}$ atividade - Corrigir o trabalho de casa e pedir que os alunos o apresentem em LIBRAS.

Nesse momento do encontro, é importante que o professor, a partir das narrativas, destaque alguns pontos, como, por exemplo, as características da personagem principal e como elas dialogam com a visão sobre a mulher na sociedade de hoje em dia.

$10^{a}$ atividade - Finalizar nossa discussão propondo um desafio para a turma. A melhor história criada será escolhida pela turma e todos, em uma atividade em grupo, montarão uma peça de teatro sobre ela nos encontros seguintes. 


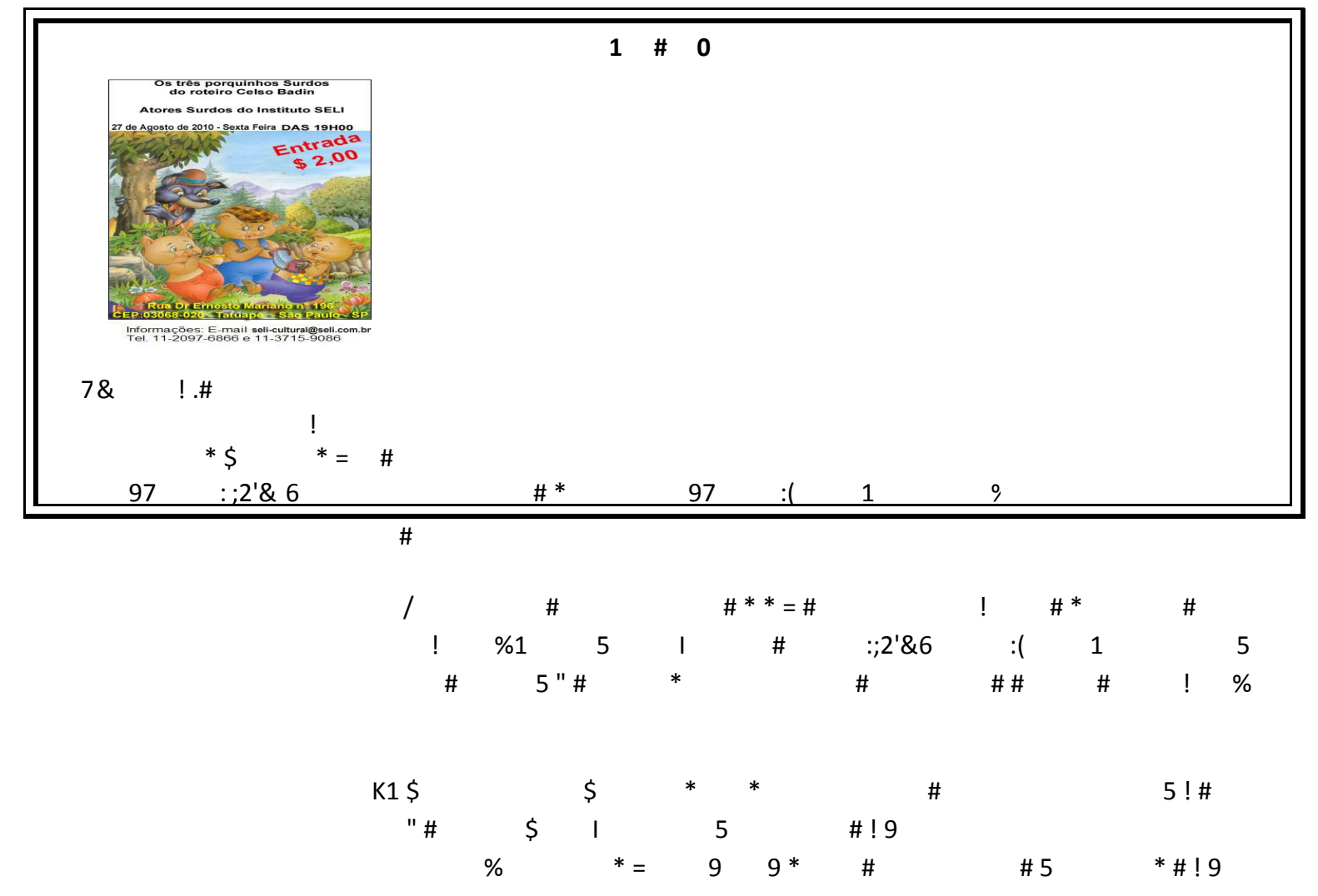

\section{5) Considerações finais}

O presente trabalho teve como objetivo propor práticas pedagógicas que trabalhassem com gêneros e tipos textuais no ensino de Português como segunda língua para surdos. Levando em conta que o ensino deve desenvolver competências linguísticas que possibilitam a formação de sujeitos ativos nas práticas mediadas pela linguagem e que questionam e imprimem mudanças no mundo ao qual pertencem, o trabalho com textos autênticos mostrase um caminho, já que os gêneros são fenômenos sócio-históricos e atividades sóciodiscursivas (Marcuschi, 2002). Além disso, como a língua tem como traço mais marcante sua função social, a utilização de gêneros e tipos textuais é fundamental para que o ensino não busque apenas trabalhar com o sistema, mas também com as práticas sociais e discursivas nas quais a comunicação se insere.

Esse tipo de reflexão promove também o letramento do aprendiz, pois lhe permite reconhecer e produzir diversos textos em diferentes domínios. No caso da comunidade surda, por não haver uma escrita da língua de sinais reconhecida, muitas vezes, seu poder de ação em determinados domínios é limitado por não dominar tão bem a modalidade escrita do Português. Logo, o incentivo à exposição do aluno surdo a diferentes contextos de uso da língua e o ensino 
das práticas discursivas a partir de uma perspectiva social e funcional também são formas de promover o empoderamento da comunidade surda e sua independência no uso da língua.

Por fim, para que preconceitos e reducionismos sejam combatidos, as reflexões sobre o ensino do Português como segunda língua para surdos e sobre as especificidades desse público mostram-se fundamentais quando pensamos em práticas pedagógicas cujos objetivos sejam retratar a história e produção cultural dessa comunidade e divulgar esses conteúdos na comunidade ouvinte. Mudar a perspectiva e o olhar que temos em relação à comunidade surda é um fator fundamental para que haja a real integração entre surdos e

ouvintes. É necessária uma educação que vise à participação integrada de todos nos estabelecimentos de ensino regular, reestruturando o ensino para que ele leve em conta a diversidade dos alunos e atente para as suas singularidades.

\section{6) Referências bibliográficas}

Bakhtin, M. (2000). Os gêneros do discurso. In: M. Bakhtin. Estética da criação verbal. São Paulo: Martins Fontes.

Bartlett, F. C. (1932). Remembering: a study in experimental and social psychology. Cambridge: Cambridge University Press.

Bronckart, J. P. (1999). Atividade de linguagem, textos e discursos: por um interacionismo sociodiscursivo (A. R. Machado, Trad.). São Paulo: Educ.

Byrne, D. (1988). Teaching writing skills. London: Longman.

Fernandes, S. (2006). Práticas de letramentos na educação bilíngue para surdos. Curitiba: SEED.

Hedge, T. (1988). Writing. Oxford: Oxford University Press.

Köche, V. S., Boff, O. M. B. \& Marinello, A. F. (2013). Leitura e produção textual: gêneros textuais do argumentar e expor. Rio de Janeiro: Vozes.

Lebedeff, T. B. (2010). Aprendendo a ler "com outros olhos": relatos de oficinas de letramento visual com professores surdos. Cadernos de Educação, 36, 175-190.

Marcuschi, L. A. (2002). Gêneros textuais: definição e funcionalidade. In: A. P. Dionísio et al (org.). Gêneros textuais e ensino. Rio de Janeiro: Lucerna.

Mcdonough, J.; Shaw, C. (1993). Materials and Methods in ELT. Oxford: Blackwell, Shaw.

Nunan, D. (1999). Second language teaching and learning. Boston, Mass: Heinle and Heinle.

Oliveira, S. (2006). Texto visual e leitura crítica: o dito, o omitido, o sugerido. Linguagem \& Ensino, 9, 15-39.

Revista Escrita

Rua Marquês de São Vicente, 225 Gávea/RJ CEP 22451-900 Brasil

Ano 2017. Número 22. ISSN 1679-6888. escrita@ puc-rio.br 
Raimes, A. (1983). Techniques in Teaching Writing. New York: Oxford University Press.

Reily, L. (2003). As imagens: o lúdico e o absurdo no ensino de arte para pré-escolares surdos. In: I. Silva; S. Kauchakje \& Z. Gesueli (org.). Cidadania, surdez e linguagem. São Paulo: Plexus.

Saliés, T. M. G. (2011). Ensino-aprendizagem de PL2 na Comunidade Surda à luz de estudos em aquisição de L2. Linguística Aplicada e Sociedade. Rio de Janeiro: CBLA - ALAB.

Tomlinson, B. (1999). Developing materials for materials evaluation. IATEFL Issues, 1013.

Tribble, C. (1996). Writing. Oxford: Oxford University Press.

Vilela, M., Koch, I. V. (2001). Gramática da língua portuguesa: gramática da palavra, gramática da frase, gramática do texto/discurso. Coimbra: Almedina.

White, R. V. (1981). Reading. In: K. Johnson \& K. Morrow (eds.). Communication in the Classroom. London: Longman.

White, R.; Arndt, V. (1991). Process Writing. London: Longman. 